\title{
Synthesis and Evaluation of Al203_Mg/AA6061 Aluminium Foam Composite via Compaction and Sintering
}

\author{
Devendra Pratap Singh 1,2,3*, Mayank Agarwal 4 \\ ${ }^{1}$ GLA University, Mathura 281406, India \\ ${ }^{2}$ Pranveer Singh Institute of Technology, Kanpur 209305, India \\ ${ }^{3}$ Dr. A.P.J. Abdul Kalam Technical University, Lucknow 226031, India \\ ${ }^{4}$ Institute of Engineering Technology, Dr. Ram Manohar Lohia Avadh University, Ayodhya, India
}

\begin{abstract}
In this paper compressive behaviour of an Aluminium foam composite have been evaluated and discussed. The outcome reflects that quasi static stress -strain curve of $\mathrm{Al}$ composite was same as to $\mathrm{Al}$ foams. However, within the two strain ranges from strain less than 0.03 and strain greater than 0.2 , the ideal absorption energy of the composites was higher than that of parent $\mathrm{Al}$ foams. When the strain ranged from 0.03 to 0.2 the ideal energy absorption efficiency value of the composite was lower than the Al foams. There are many methods for fabricating metal foams but we preferred powder metallurgy process. This process of production allows for the production of complex shaped foam parts. Many alloys including Aluminium, zinc, tin, lead and steel can be produced using this method. The fabricated part has a closed cell microstructure and a high fraction of porosity. Mechanical properties foams are evaluated including the axial crushing, Hardness and toughness test are also carried out. Applications are such as light weight construction and energy absorption for civilians as well as military uses.
\end{abstract}

Key words: Al foam, Powder metallurgy, AA6061, Sintering

\section{Introduction}

6061 (Unified Numbering System (UNS) designation A96061) is a precipitation-hardened aluminium alloy, containing magnesium and silicon as its major alloying elements. Originally called "Alloy 61S", it was developed in 1935. It has good mechanical properties, exhibits good weld ability, and is very commonly extruded (second in popularity only to 6063). It is one of the most common alloys of aluminium for generalpurpose use. [1-8]

It is commonly available in pre-tempered grades such as 6061-O (annealed), tempered grades such as 6061T6 (solutionized and artificially aged) and 6061-T651 (solutionized, stress-relieved stretched and artificially aged). [9-10]

Aluminium metal foams are produced with various methods like powder metallurgy technique, sintering technique, addition of gas in melt injection, using agent in melt foaming, and investing casting. The maximum parameters of every method combination of properties to the material, so there are a unit several samples of optimization of method in literature however due to method complexity and hazard, though all the efforts to develop foams at cheaper procedure. [11,13-15] Metal foams are materials that show distinctive combination of physical and mechanical properties like lightweight, high specific stiffness, high strength to weight ratios, and greatly increased energy absorbing capabilities create use within the automotive and aerospace industries. It's additionally shown to expertise fatigue degradation in each tension and compression.[12] aluminium metal Foam is taken into account as a material that's solid under low stress however it flows like a fluid beneath high stress. There's a precise vary of strain over those foams are elastic in nature and their deformation recoverable. Foams are having distinctive property combination of low density, competitive weight specific mechanical properties and high energy absorption.[16] thence drawbacks of today's most popular production methodology, the powder metallurgical process, that is predicated on a precursor material incorporating a 
foaming agent, area unit comparatively high production prices also as attain smart material properties. By this methodology produced a replacement form of closed cell foams by filling the vacancies around a random dense collection of preformed hollow spheres with a solid matrix material, either through casting or through powder metallurgy method with the aim of increasing their energy absorption and strength. Metallic foams made via a powder metallurgy technique by heating a compacted mixture, foamable precursor, of Aluminium alloy powders and a foaming agent. [17-20] The powder metallurgy foaming method is fast with expansion occurring takes place during a few minutes useable cellular structure of foam obtained. In this review paper identifies best suitable production methods for production of aluminium metal foam so that which will give the good result over analysis on mechanical application. [21-22]

In this paper we will discuss the fabrication of aluminium foam which is to prepared with the help of a consolidated process of powder compaction process and conventional casting and analyse the change in mechanical properties. In this work a consolidated effect of compaction and casting will be introduced with use of wax, which is provide an investment casting effect for the aluminium metallic foam.

\section{Fabrication And Testing}

Aluminium metallic foam AA6061 was prepared by using magnesium (Mg) and aluminium oxide (Al2O3) composite via compaction and sintering. Four samples having different wt\% of $\mathrm{Al} 2 \mathrm{O} 3$ and $\mathrm{Mg}$ as its main alloying element and also Aluminium powder, wax, Aluminium Chip, are prepared in following proportion shown in table-1.

Table-1: Composition of alloying elements by weight (in gm) present in Aluminium Metallic Foam

\begin{tabular}{|l|c|c|c|c|}
\hline \multirow{2}{*}{ Components } & Sample1 & Sample2 & Sample3 & Sample4 \\
\cline { 2 - 5 } & \multicolumn{5}{|c|}{ (Wt. in gm) } \\
\hline $\mathrm{Al}$ (Powder) & 60 & 60 & 60 & 60 \\
\hline $\mathrm{Mg}$ (Powder) & 3 & 6 & - & - \\
\hline $\mathrm{Al}_{2} \mathrm{O}_{3}$ (Powder) & - & - & 3 & 6 \\
\hline $\mathrm{Al}$ (chip) & 20 & 20 & 20 & 6 \\
\hline $\mathrm{Wax}$ & 6 & 6 & 6 & 20 \\
\hline
\end{tabular}

Processing starts with mixing of Alumina, Mg (Magnesium powder), Aluminium powder, wax via ball milling process in the certain proportion given in table-1 to grinds different grain size material into extremely fine powders. After mixing all materials gelatine and hot water have been added in blended powder and mix it and make a thick paste. The thick paste is then compacted into a shape inside the die and compressed via UTM machine and then ejected from the die cavity as shown in fig. 1. Then prepared composites are heated in a controlled atmosphere (sintering) to reduces porosity and enhances properties such as strength, electrical conductivity, translucency and thermal conductivity; due to atomic diffusion which drives powder surface elimination in different stages, starting from the formation of necks between powders to final elimination of small pores. Machining, Polishing process performed after sintering to make specimen ready, as shown in fig. 2 , for the testing and evaluation of mechanical properties.

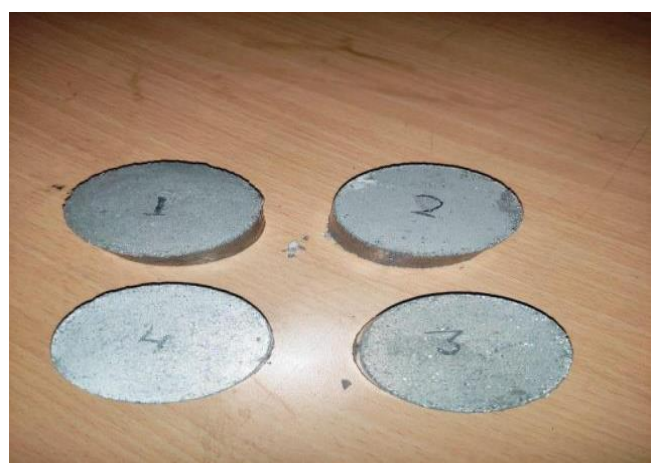

Fig.1: Prepared Sample 1, Sample2, Sample3 and Sample4 using different wt\% of alloying element 


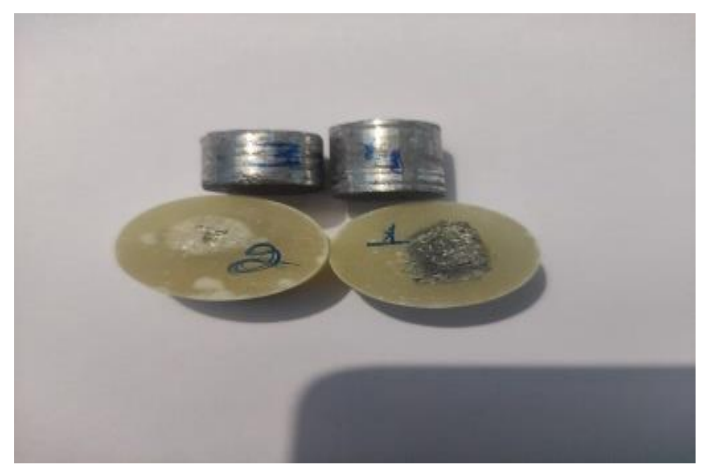

Fig.2: Final sample ready for testing after machining and polishing.

Specimens are prepared as per ASTM E 10 standards (specimen thickness at least 10 times of the indentation depth, and indentation time 10-15 sec) for hardness testing in Brinell hardness testing machine as indentation leaves a relatively large impression, the Brinell hardness test is better suited to larger samples with a coarse or inhomogeneous grain structure, such as castings and forgings. In all hardness tests, the material under the indent should be representative of the whole microstructure. Therefore, if a microstructure is very coarse and heterogeneous, a larger impression required than for a homogeneous material. Measured depression diameter for HBW 2.5/187.5 test (2.5 mm tungsten carbide ball and $187.5 \mathrm{kgf}$ load) are shown in table-2.

Table-2: Values of depression diameter for HBW 2.5/187.5 test

\begin{tabular}{|c|c|c|c|}
\hline LOAD (kgf) & $\begin{array}{c}\text { Dia. of Indenter } \\
(\mathbf{m m})\end{array}$ & $\begin{array}{l}\text { Dia. of Indentation } \\
(\mathbf{m m})\end{array}$ & $\mathrm{BHN}\left(\mathrm{N} / \mathrm{mm}^{2}\right)$ \\
\hline 187.5 & 2.5 & 1.8 & 624.44 \\
\hline 187.5 & 2.5 & 1.7 & 702.41 \\
\hline 187.5 & 2.5 & 1.6 & 807.36 \\
\hline
\end{tabular}

Also, to test lateral instability due to buckling action, Compressive strength of specimen have been tested by placing the specimen between the compression plates at its centre position such a way that the moving head's centre is placed vertically above the centre of the specimen and then the load is applied by giving direction to advancing the head until the specimen breaks down. $21 \mathrm{kN}, 25 \mathrm{kN}, 27 \mathrm{kN}$, and $30 \mathrm{kN}$ load applied on cylindrical specimen of diameter $15 \mathrm{~mm}$ (cross-sectional area $176.625 \mathrm{~mm}^{2}$ ) to get ultimate strength.

\section{Result And Discussion}

Experimental results for Brinell Hardness test and compression test for various samples are shown in table-3.

Table-3: Average Experimental results of hardness and compression test

\begin{tabular}{|c|c|c|c|c|}
\hline Test Parameters & Sample1 & Sample2 & Sample3 & Sample4 \\
\hline BHN (N/mm $\left.{ }^{\mathbf{2}}\right)$ & 624.44 & 807.7 & 702.41 & 807.73 \\
\hline $\begin{array}{c}\text { Ultimate strength } \\
\left(\mathbf{N} / \mathbf{m m}^{2}\right)\end{array}$ & 118.89 & 141.54 & 152.86 & 169.85 \\
\hline
\end{tabular}

The hardness of the foam sample depends on density, the bonding between the powder particles. The hardness of 2 nd foam sample is relatively higher as compared to 1st, because of increased density and the less micro porosity increases the hardness of foam which is higher also as compared to aluminium.

The results of quasi-static (Q-S) compression testing in the form of observed engineering stress-strain relationship show a characteristic compressive behaviour of cellular materials. After an initial quasi-linear response, the cell walls start to bend and buckle resulting in the stress plateau, which is typical for cellular materials. The cell walls begin to fracture with further deformation and the cells gradually collapse, finally leading to the densification of the cellular structure. 
The resulting deviation is a consequence of the aluminium foam density variation throughout the specimens $\left(628-713 \mathrm{~kg} / \mathrm{m}^{3}\right)$, which strongly influences the mechanical behavior. Studies have demonstrated that these foams develop imperfections and structural defects (e.g., micro pores) during their fabrication, creating weaker regions where the foam starts to deform, developing one or more visible deformation bands perpendicular to the loading direction. The stiffness of the specimens increases by increasing the foam density. Also, the plateau region of these specimens is slightly inclined. This agrees with our previous results. For these types of foams. As can be seen from Figure 3, the deformation behavior is uniform at lower strains, which is followed by crushing in shear planes that are formed in the areas with less cellular structure.
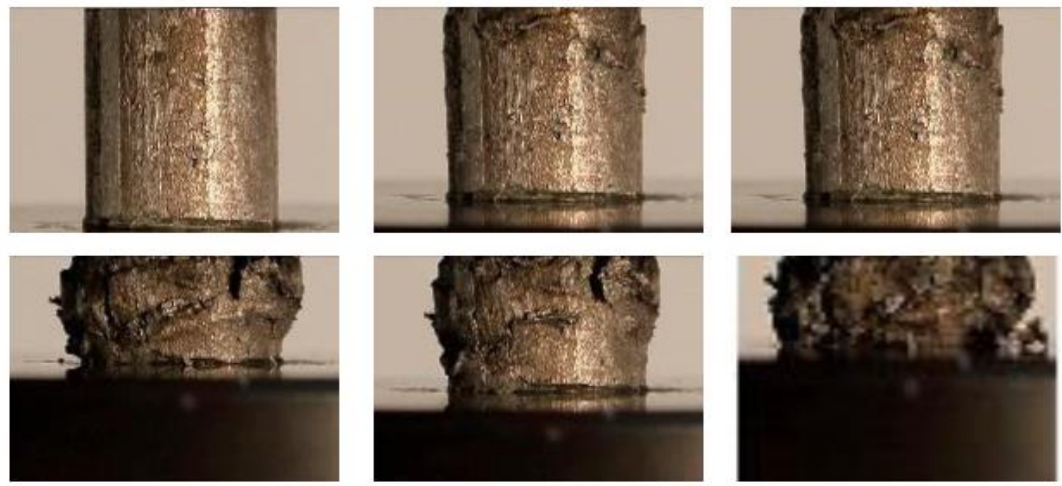

Fig.3: Deformation sequence of closed-cell aluminium foam under quasi-static loading conditions

\section{Conclusion}

This paper reports the history of metallic foam, different types of fabrication process as casting methods, powder metallurgy process. Four work pieces have been prepared by powder metallurgy process, casting methods is use only mass production process.

Our environment having different materials by which one can prepare the structural member for building application, automobile application etc. but sometimes these application wants different property with same materials then single type material does not fulfil the need of application so Al203_Mg/AA6061 Aluminium alloy has been developed in which both results are existing in a single time.

To fulfil the need of light weighted material with hardness, magnesium is alloyed with Al. To combined both property powder metallurgy process has been used. Casting methods is used for mass production process.

After compaction process, work pieces tested for the hardness and compressive strength and the results indicated in table-4 suggests improved mechanical properties than $\mathrm{Al}$ alloys and mild steel.

Table-4: Comparison among Al2O3_Mg/AA6061 and pure aluminium alloy, and mild steel

\begin{tabular}{|c|c|c|c|}
\hline $\begin{array}{c}\text { Mechanical } \\
\text { Property }\end{array}$ & Mild Steel & Aluminium Alloy & Al2o3_Mg/AA6061 \\
\hline $\begin{array}{c}\text { Brinell Hardness } \\
\left(\mathrm{N} / \mathrm{mm}^{2}\right)\end{array}$ & 126 & 245 & 736 \\
\hline $\begin{array}{c}\text { Compressive } \\
\text { Strength }\left(\mathrm{N} / \mathrm{mm}^{2}\right)\end{array}$ & 250 & 30 & 145 \\
\hline $\begin{array}{c}\text { Melting } \\
\text { Temperature }\left({ }^{\circ} \mathrm{C}\right)\end{array}$ & $1350-1530$ & 655 & $950-1350$ \\
\hline
\end{tabular}

\section{Refrences}

1. Antenucci, A., S. Guarino, V. Tagliaferri, and N. Ucciardello. "Improvement of the mechanical and thermal characteristics of open cell aluminum foams by the electrodeposition of $\mathrm{Cu}$." Materials \& design 59 (2014): 124-129.

2. Rabiei, Afsaneh, Lakshmi Vendra, Nick Reese, Noah Young, and Brian P. Neville. "Processing and characterization of a new composite metal foam." Materials transactions 47, no. 9 (2006): 21482153. 
3. Paknezhad, M., A. M. Rashidi, T. Yousefi, and Z. Saghir. "Effect of aluminum-foam heat sink on inclined hot surface temperature in the case of free convection heat transfer." Case Studies in Thermal Engineering 10 (2017): 199-206.

4. . Mirzaali, M. J., F. Libonati, P. Vena, V. Mussi, L. Vergani, and M. Strano. "Investigation of the Effect of Internal Pores Distribution on the Elastic Properties of Closed-Cell Aluminum Foam: A Comparison with Cancellous Bone." Procedia Structural Integrity 2 (2016): 1285-1294.

5. Manca, Oronzio, Luca Cirillo, Sergio Nardini, Bernardo Buonomo, and DavideErcole. "Experimental Investigation on Fluid Dynamic and Thermal Behavior in Confined Impinging Round Jets in Aluminum Foam." Energy Procedia 101 (2016): 1095-1102.

6. D. B. Spencer, R. Mehrabian, and M. C. Flemings, "Rheological behavior of Sn-15 pctPb in the crystallization range," Metallurgical Transactions, vol. 3, no. 7, pp. 1925-1932, 1972.

7. P. Kapranos, D. H. Kirkwood, and C. M. Sellars, "Semisolid processing of aluminum and high melting point alloys," Proceedings of the Institution of Mechanical Engineers B, vol. 207, no. 1, pp. $1-8,2004$.

8. P. J. Ward, H. V. Atkinson, P. R. G. Anderson et al., "Semi-solid processing of novel MMCs based on hypereutectic aluminiumsilicon alloys," ActaMaterialia, vol. 44, no. 5, pp. 1717-1727, 2001.

9. T. Motegi, K. Kondou, C. Lui, and S. Aoyama, "Continuous Casting of Semisolid Al-Si-Mg Alloy," in Proceedings of the 4th Decennial International Conference on Solidification Processing, vol. 7, pp. 14-16, 1997.

10. Ullmann, Fritz (2005). Ullmann's Chemical Engineering and Plant Design, Volumes 1-2. John Wiley \& Sons.

11. Sclater, J.G. \& Christie, P.A.F. 1980. Continental stretching: an explanation of the post-midCretaceous subsidence of the Central North Sea Basin. Journal of Geophysical Research, 85, 37113739.

12. "Sinter, v." Oxford English Dictionary Second Edition on CD-ROM (v. 4.0) () Oxford University Press 2009

13. Takacs, Laszlo (January 2002). "Self-sustaining reactions induced by ball milling". Progress in Materials Science. 47 (4): 355-414

14. R.B. Clancy, J.K. Cochran, T.H. Sanders Jr., Fabrication and properties of hollow sphere nickel foams, Mater. Res. Soc. Symp. Proc. 372 (1995) 155e163

15. S. Guarino, M. Barletta, S. Pezzola, S. Vesco, Manufacturing of steel foams by slip reaction foam sintering (SRFS), Mater. Des. 40 (2012) 268e275.

16. Y. Yang, S. Shimai, Y. Sun, M.J. Dong, H. Kamiya, S.W. Wang, Fabrication of porous Al2O3 ceramics by rapid gelation and mechanical foaming, J. Mater. Res. 28 (2013) 2012e2016.

17. Y. Hangai, H. Yoshida, N. Yoshikawa, Friction powder compaction for fabrication of open-cell aluminum foam by the sintering and dissolution process route, Metall. Mat. Trans. A 43 (2012) $802 \mathrm{e} 805$.

18. N. Michailidis, F. Stergioudi, Establishment of process parameters for producing Al-foam by dissolution and powder sintering method, Mater. Des. 32 (2011) 1559e1564.

19. ] N. Michailidis, F. Stergioudi, D.N. Tsipas, Manufacturing of open-cell metal foams using a novel leachable pattern, Adv. Eng. Mater. 13 (2011) 29e32.

20. D.P. Mondal, S. Das, N. Ramakrishnan, K. Uday Bhasker, Cenosphere filled aluminum syntactic foam made through stir-casting technique, Compos. Part A Appl. Sci. Manuf. 40 (2009) 279-288.

21. M.F. Ashby, A.G. Evans, N.A. Fleck, L.J. Gibson, J.W. Hutchinson, H.N.G. Wadley, Metal Foams : A Design Guide Metal Foams : A Design Guide, (2000).

22. A.R.E. Singer, Metal Matrix Composites Made by Spray Forming, Mater. Sci. Eng. a-Structural Mater. Prop. Microstruct. Process. 135 (1991) 13-17 